Mr. C. Boden Kloss, until recently Director of Museums in Malaya, writes (in litt.) of a similar experience off Batticaloa in Ceylon. He refers to the sound as "piping . . . something like the note of the Singapore bull-frog made fluty and musical".

The name given by the Malays to some fishes of the genera Therapon and Centrogenys is kérongkĕrong, mĕnkerong or tënkerong 1 .

Dr. C. O. Blagden, of the School of Oriental Studies, tells me that the meaning of kerrong is a deep metallic or booming sound, and agrees with my suggestion that it is of onomatopœic origin. This would account for the Malay name of Dr. Hardenberg's fish, and show that the phenomenon is known to the natives. (I have not been able to see a copy of Dr. Hardenberg's paper so do not know whether he has discussed this.)

On the east coast of the Peninsula the Malay fishermen employ a juru seelam (literally 'diving expert', fide Dr. Blagden). He dives under the surface, listens for the fishes, and is said to be capable of guiding the boats. His activities (an account of which appears in a report by Mr. Birtwistle issued, if memory serves, about 1928) have been looked upon with a tolerant incredulity by Europeans in Malaya. In view of the above, however, it appears that they may have at least a basis of fact.

Norman Smedley.

Art Gallery and Museum,

Waterdale, Doncaster. April 8.

${ }^{1}$ Maxwell, C. N., J. Straits Branch Roy. Asiat. Soc., No. 84.

\section{Activation of Cambial Growth by Pure Hormones}

IN a recent letter to NATURE ${ }^{1}$ it was reported that strong cambial growth can be activated in young decapitated sun-flower seedlings by inserting their upper ends into tubes containing a weak solution in gelatine of the ether-soluble component of urine. With a similar method it has now been found that strong cambial growth can be activated by solutions of pure auxin- $a$ and of pure $\beta$-indoly]-acetic acid (called by $\mathrm{Kogl}^{2}$ 'hetero-auxin') at concentrations of 1 or 2 in $10^{6}$. The auxin- $a$ was kindly sent by Prof. Kogl from Utrecht, and the hetero-auxin was kindly synthesised by Dr. Weisberger at the Dyson Perrins Laboratory, Oxford. The cambium formed was in the normal position, and it extended for at least three centimetres below the part to which the hormone was applied. Controls had formed no cambium, or scarcely any.

Thus the same hormones, auxin- $a$ and heteroauxin, which promote the elongation of stems and coleoptiles, also activate growth in thickness by divisions of cambial cells, besides activating root. formation ${ }^{3,4}$ and producing various other effects. According to $\mathrm{Kogl}^{2}$, auxin- $a$ is the hormone formed by the tips of grass seedlings, whereas hetero-auxin is formed by yeast. For experiments on growth, the use of pure hetero-auxin, which can be synthesised in ample quantities, should prove very valuable.

\section{Department of Botany,}

R. SNow. Oxford.

\footnotetext{
1 Snow and Le Fanu, Nature, 135, 149, Jan. 26, 1935.

${ }^{2} \mathrm{Kogl}$, Ber deutsch. chem. Ges., 68, 16; 1935.

${ }^{3}$ Thimann and Went, Proc. Kon. Akad. Wetensch. Amsterdam, 37, $456 ; 1934$.

- Thimann and Koepfli, NATURE, 135, 101, Jan. 19, 1935.
}

\section{Tetraploid Sweet Peas}

Lathyrus odoratus has been classical material for genetic study ever since the rediscovery of Mendel's work. But up to now, no chromosomal aberrations of any kind have ever been found. The sweet pea, in common with all other species of Lathyrus hitherto investigated, has seven regular bivalents at meiosis. It is therefore of interest to report here the first discovery of tetraploidy in this plant.

In a family growing at this Institution, Miss C. Pellew noticed a plant with constricted pods, such as are typical of the half-sterile heterozygous translocation plants in Pisum. The plant was very vigorous and set a large number of pods which, however, contained but few seeds-never more than four, instead of the usual 8-12. Owing to the lateness of the season, no preparations of pollen mother-cell divisions could be made, but mitoses were found in petals and sepals which showed the plant to be tetraploid. The root-tips of ten seedlings obtained by selfing this plant were examined cytologically, and in every case a complement of 28 chromosomes was found.

The family in which the tetraploid plant appeared was an $F_{2}$ segregating for four recessive factors: copper, acacia, glabrous and dull-the last three being in one linkage group. The tetraploid plant was dominant for all four genes; it is thus not improbable that some factors will be available for the study of tetrasomic segregation in sweet peas.

A. C. Faberge.

John Innes Horticultural Institution, Mostyn Road, Merton Park, London, S.W.19. March 29.

\section{Inhalation of Carbon Dioxide at High Altitudes}

THE suggestion put forward in NATURE of March 23 (p. 457) by Prof. Yandell Henderson and others to the effect that carbon dioxide might be of use in high altitude climbing reminds me of some trials carried out about ten years ago. Messrs. Siebe Gorman and Co., Ltd., had similar ideas, and they lent me a rebreathing mask to try out in the Alps. I went up to the Margherita hut on Monte Rosa, to all intents $15,000 \mathrm{ft}$., to test it. I was in fairly good training at the time, but had not been above about $12,000 \mathrm{ft}$. that summer. For trial purposes this was all to the good, as I became rather blown during the last thousand feet, having walked up fast to the 14,000 ft. level. It may therefore be assumed that I was partially but not fully acclimatised.

The moment I started to rest at the hut I felt perfectly fit, and after lunch I lay down for 20 minutes or so, before starting the test. I then noted pulse and respiration rates, put on the mask and noted them again. I have not a record of the figures handy, but can definitely state from memory that there was an almost immediate drop of 20-25 per cent in each rate.

I am afraid I did not try the mask while walking uphill ; but a device which weighs fewer ounces than a gas bottle weighs pounds might be worth thinking seriously about. On the other hand, it is quite possible that it might defeat its own object, by supplying carbon dioxide at the expense of oxygen. However, the experiment is so simple that it should be tried 